Article

\title{
Fucoidans of Moroccan Brown Seaweed as Elicitors of Natural Defenses in Date Palm Roots
}

\author{
Soukaina Bouissil ${ }^{1,2}$, Zainab El Alaoui-Talibi ${ }^{1}$, Guillaume Pierre ${ }^{2} \mathbb{1}$, Halima Rchid ${ }^{3}$, \\ Philippe Michaud $^{2}{ }^{(1)}$, Cédric Delattre ${ }^{2,4, *}$ (D) and Cherkaoui El Modafar ${ }^{1}$ \\ 1 Laboratoire d'Agrobiotechnologie et Bioingénierie, Faculté des Sciences et Techniques Marrakech, \\ Université Cadi Ayyad, Marrakesh 40000, Morocco; soukaina.BOUISSIL@etu.uca.fr (S.B.); \\ Z.elalaouitalibi@uca.ma (Z.E.A.-T.); elmodafar@uca.ac.ma (C.E.M.) \\ 2 Institut Pascal, Université Clermont Auvergne, CNRS, SIGMA Clermont, F-63000 Clermont-Ferrand, France; \\ guillaume.pierre@uca.fr (G.P.); philippe.michaud@uca.fr (P.M.) \\ 3 Laboratoire de Biotechnologies et Valorisation des Ressources Végétales, Faculté des Sciences, \\ Université Chouaib Doukkali, El Jadida 24000, Morocco; rchid.h@ucd.ac.ma \\ 4 Institut Universitaire de France (IUF), 1 Rue Descartes, 75005 Paris, France \\ * Correspondence: cedric.delattre@uca.fr
}

Received: 9 November 2020; Accepted: 25 November 2020; Published: 26 November 2020

check for updates

\begin{abstract}
Fucoidans from Moroccan brown seaweed Bifurcaria bifurcata and Fucus spiralis were tested for their elicitor activity after their purification and complete characterization. The fucoidans of B. bifurcata (BBF) and of $F$. spiralis (FSF) were extracted and purified then characterized by infrared spectroscopy, proton nuclear magnetic resonance spectroscopy and size exclusion chromatography. The results show that BBF and FSF are mainly sulfated with 45.49 and $49.53 \%(w / w)$ sulfate, respectively. Analysis of neutral sugars determined by gas chromatography-mass spectrometry showed that FSF and BBF were mainly composed of $64 \%$ and $91 \%$ fucose and $20 \%$ and $6 \%$ galactose, respectively, with a few other sugars such as glucose ( $8 \%$ in FSF), rhamnose ( $1 \%$ in BBF) and mannose ( $8 \%$ in FSF and, $2 \%$ in BBF). The eliciting activity of these sulfated polysaccharides in stimulating the natural defenses of the date palm was evaluated through the activity of phenylalanine ammonia-lyase (PAL), and the increase in phenols and lignin content in the roots. The results obtained clearly show that the two fucoidans early and intensely stimulate the natural defenses of the date palm after $24 \mathrm{~h}$ of treatments. This remarkable elicitor effect seems to be linked to the sulfated groups compared to non-sulfate alginates extracted from the same algae. These results open promising perspectives for a biological control approach against date palm diseases.
\end{abstract}

Keywords: sulfated polysaccharides; natural defenses; phenolic metabolism; phenylalanine ammonia-lyase

\section{Introduction}

Sulfated polysaccharides are increasingly recognized for their broad spectrum of biological activities. They usually found in large quantities in brown seaweeds. In addition, the polysaccharides structures depend on the algae species. Thus, various biological activities could be discovered with each new sulfated polysaccharide extraction [1].

Amongst these polysaccharides, the most studied was carrageenan [2], ulvan [3] and fucoidans. Fucoidans at the molecular level constitute a polymer of L-fucose linked by $(1,3)$ and $(1,4)$ with residues mainly sulfated on C-4 [4,5]. The characteristic structure of fucoidans rich in L-fucose and sulfated ester groups has generated widespread interest due to their therapeutic effects. Several works reported the biological proprieties of fucoidans [6], namely antioxidant [7,8], antitumor [9-12] and anticoagulant [13]. 
In addition to these biological applications, fucoidans and their oligosaccharides have also been the subject of other studies on biostimulants of defence mechanisms in plants [14,15]. They were also suggested as biological approaches to control plants disease [16], by benefiting from their stimulating effect of early and late defensive responses. It is reported that biological and biostimulant properties of fucoidans depend in particular on the degree of sulfation [8] and on their various physico-chemical properties [5].

The aim of this work is to study the potential activity of fucoidans to elicit the natural defence mechanisms in date palm (Phoenix dactylifera $\mathrm{L}$.) roots as a monocotyledon plant. Through an innovative elicitation model allowing the treatment of the roots which are the site of infection of the date palm by Fusarium oxysporum $\mathrm{f}$. sp. albedinis (Foa), a telluric pathogen causing the fatal disease (Bayoud) of date palm [17]. In response to Bayoud disease, date palm develops numerous defence mechanisms in roots such as the induction of phytoalexins [18], the accumulation of caffeoyl shikimic acids $[19,20]$ and the reinforcement of the cell walls by lignin and phenolic compounds [21]. These defence mechanisms all depend on, phenylalanine ammonia-lyase (PAL) activity, triggering the phenlypropanoid pathway [17]. The activity of this enzyme governs the defence mechanisms induced in sensitive and resistant varieties during a date palm and Foa interactions [22]. In this context crude fucoidans, extracted from two brown algae Bifurcaria bifurcata and Fucus spiralis from the Atlantic coast of Morocco were structurally characterized and tested for their possible eliciting effect on the defence mechanisms of the date palm roots.

\section{Results and Discussion}

\subsection{Chemical Composition of Crude Fucoidans}

The abundance of the two brown algae B. bifurcata and F. spiralis on the Moroccan Atlantic coast was the reason for the choice of these two species. The yield as well as the chemical composition of the fucoidans extracted from these species are shown in Table 1. FSF and BBF yields were around 8 and $2 \%$, respectively, based on algae dry weight.

Table 1. Chemical composition and yield of F. spiralis (FSF) and B. bifurcata (BBF) crude fucoidans.

\begin{tabular}{ccc}
\hline Analytical Data $(\%, \boldsymbol{w} / \boldsymbol{w})$ & FSF & BBF \\
\hline Yield $^{\mathrm{a}}$ & 7.9 & 1.9 \\
Neutral sugar $^{\mathrm{b}}$ & 51.16 & 45.23 \\
Uronic acids $^{\mathrm{b}}$ & 14.68 & 21.79 \\
Sulfates $^{\mathrm{b}}$ & 49.53 & 45.49 \\
Protein $^{\mathrm{b}}$ & Traces & Traces \\
$\mathrm{M}_{\mathrm{w}}(\mathrm{g} / \mathrm{mol})^{\mathrm{c}}$ & $20 \times 10^{3}$ & $14 \times 10^{3}$ \\
\hline
\end{tabular}

${ }^{a}$ Expressed on the weight of dry depigmented algae. ${ }^{\mathbf{b}}$ Expressed on the weight of dry fucoidans. ${ }^{\mathbf{c}}$ Molecular weight by High Performance Size Exclusion Chromatography (HPSEC) analysis.

Colorimetric assays show that FSF and BBF contained principally neutral sugar from 45.23 to 51.16 for B. bifurcata (BBF) and of F. spiralis (FSF), respectively, those extracted fucoidans were also highly sulfated (FSF, $49.53 \%$ and BBF, $45.49 \%$ ).

The main neutral sugars which constitute FSF and BBF was determined by gas chromatographymass spectrometry (GC-MS) analysis and the result reported in Table 2 shows that was the L-fucose with 63.98 and $90.68 \%$, respectively, based on dry weight of sulfated polysaccharides (FSF and BBF).

The results obtained (Table 1) are different from those demonstrated for fucoidans of B. bifurcata from Britain with a higher extraction yield $(17 \% w / w), 40-42 \%$ of carbohydrate with $22.2 \%$ of sulfates [23]. Compared to fucoidans extracted from other green algae, the BBF extraction yield remained much lower than that registered of fucoidans of Cystoseira compressa $(5.2 \% w / w)$ [24] and Cystoseira barbata $(5.45 \% w / w)$ [8], whereas, it is close to $2.8 \%$ of fucoidans purified from C. crinite and to $2.2 \%$ extracted from Dictyota dichotoma $[25,26]$, while the FSF yield was more important than that reported for the algae 
mentioned above. On the other hand, the sulfates concentration of extracted polysaccharides (FSF and BBF) was much higher than those reported for fucoidans extracted from Cystoseira and Sargassum species $[8,24,27]$. Elsewhere, fucoidans from Alaria sp. and Saccharina japonica at spore production was highly sulfated than fucoidans obtained at vegetative status of these brown algae species [28]. Thus, fucoidans' yield and their overall chemical composition could be influenced by the procreating status of seaweed [29]. L-fucose was the principal constitutive monosaccharide of FSF and BBF, with a $\mathrm{Fuc}_{\mathrm{p}} / \mathrm{Gal}_{\mathrm{p}}$ ratio of 3.2 and 14.7, respectively (Table 2), indicating a predominate amount of L-fucose than galactose. This composition was similar to that found in fucoidans of Saccharina cichorioides $\left(\mathrm{Fuc}_{\mathrm{p}} / \mathrm{Gal}_{\mathrm{p}}\right.$ ratio of 13.84 ) related to $88.6 \% \mathrm{~mol}$ of L-fucose and $6.4 \% \mathrm{~mol}$ of galactose [27]. The ratio found in this work for BBF (14.7) appeared higher than that recorded for fucoidans of S. japonica with $\mathrm{Fuc}_{\mathrm{p}} / \mathrm{Gal}_{\mathrm{p}}$ of 1.13 [27], and the ratio obtained from Undaria pinnatifida fucoidans which was equal to 1.39 [29]. More studies carried out on fucoidans reported the lower $\mathrm{Fuc}_{\mathrm{p}} / \mathrm{Gal}_{\mathrm{p}}$ ratio for fucoidans of C. compressa (2.57) [24], C. barbata (1.3) [8], Agarum cribrosum (2.63) [30], Lachemilla angustata (3.93) [31] and Fucus evanescens (8.2) [27]. The monosaccharide composition obtained for FSF and BBF reported the presence of more than $50 \%$ of L-fucose; this can explain the higher sulfate concentration in FSF and BBF. It was reported that concentration of sulfated residues depend on the nature of fucoidans monosaccharide composition [27,31].

Table 2. Monosaccharide composition of F. spiralis (FSF) and B. bifurcata (BBF) crude fucoidans.

\begin{tabular}{ccc}
\hline Monosaccharides $^{\text {a }} \mathbf{( \% ~ m o l )}$ & FSF & BBF \\
\hline Fucose & 63.98 & 90.68 \\
Galactose & 20.00 & 6.19 \\
Glucose & 8.00 & nd \\
Mannose & 7.99 & 1.65 \\
Rhamnose & nd & 1.46 \\
Fuc $_{\mathrm{p}} / \mathrm{Gal}_{\mathrm{p}}$ ratio & 3.2 & 14.7 \\
\hline
\end{tabular}

a Monosaccharides composition by GC-MS analysis, expressed as molar \% of the total identified peaks based on the weight of dry fucoidans.

\subsection{Proton Nuclear Magnetic Resonan ce $\left({ }^{1} H-N M R\right)$ and Infrared (ATR-FTIR) Spectroscopies}

To better characterize the fucoidans, an ${ }^{1} \mathrm{H}$ NMR analysis was carried out. FSF and BBF spectra are presented in Figure 1. The two spectra exhibit five regions characteristic of fucoidans. The intense peaks at 1.34 and at $1.22 \mathrm{ppm}$ are from the $\mathrm{H6}$ methyl protons of L-fucopyranose [32]. Signal at $2.14 \mathrm{ppm}$ refer to the methyl protons of the O-acetyl groups [32]. The spectrum between 4.1 and $3.7 \mathrm{ppm}$ corresponds to the protons of the ring $(\mathrm{H} 2-\mathrm{H} 5)$ [8]. The signal around $4.3 \mathrm{ppm}$, is related to the protons of the 4-O-sulfated monosaccharides [33,34]. It is more intense in the case of FSF than BBF, which corroborates the slight difference in sulfates proportions between the two samples (Table 1). Finally the signals region between 5.3 and $5.03 \mathrm{ppm}$, are attributed to the $\mathrm{C}-\mathrm{H}$ proton of substituted $\mathrm{O}=\mathrm{C}$ and to proton $\mathrm{H} 1$ of monosaccharides- $\alpha$-L-fucopyranose [32]. The spectra obtained for FSF and BBF are very similar to those obtained for fucoidans of Fucus vesiculosus and Ascophyllum nodosum [33], C. barbata [8] and C. compressa [24].

In parallel, an infrared analysis was carried out. The Attenuated Total Reflectance ATR-FTIR spectra of BBF and FSF were represented in Figure 2. The two spectra showed characteristics bands at 3406-3403, 2941, 1635-1605, 1423-1420, 1222-1223,1027-1013, 836-833, 577-574 and 479-748 cm ${ }^{-1}$ (Figure 2). The absorption peaks around 3406-3403 and $2941 \mathrm{~cm}^{-1}$ are attributed to the elongation of $(\mathrm{O}-\mathrm{H})$ and asymmetric vibrations of $(\mathrm{C}-\mathrm{H})$, respectively [35]. The signals around $1635 \mathrm{~cm}^{-1}$ were attributed to the elongation vibrations of $(\mathrm{C}=\mathrm{O})$ in uronic monosaccharides [36]. Asymmetric vibrations of elongation within O-S-O were revealed at 1222 and $1223 \mathrm{~cm}^{-1}$ indicating the presence of sulfate esters [37], whilst the elongation of sulfur dioxide $(\mathrm{O}=\mathrm{S}=\mathrm{O})$ could be indicated by the signals at 1027 and at $1013 \mathrm{~cm}^{-1}$ for BBF (Figure 2A) and FSF (Figure 2B), respectively [37]. In addition, sulfate groups linked to $\mathrm{C} 4$ of fucosyl units seem to be revealed at 836 and $833 \mathrm{~cm}^{-1}$ characteristics bands of (C4-O-S) 
elongation [38]. However, the binding of sulfate groups with galactose residues was indicated by the absorption bands at 577 and $479 \mathrm{~cm}^{-1}$ [37].
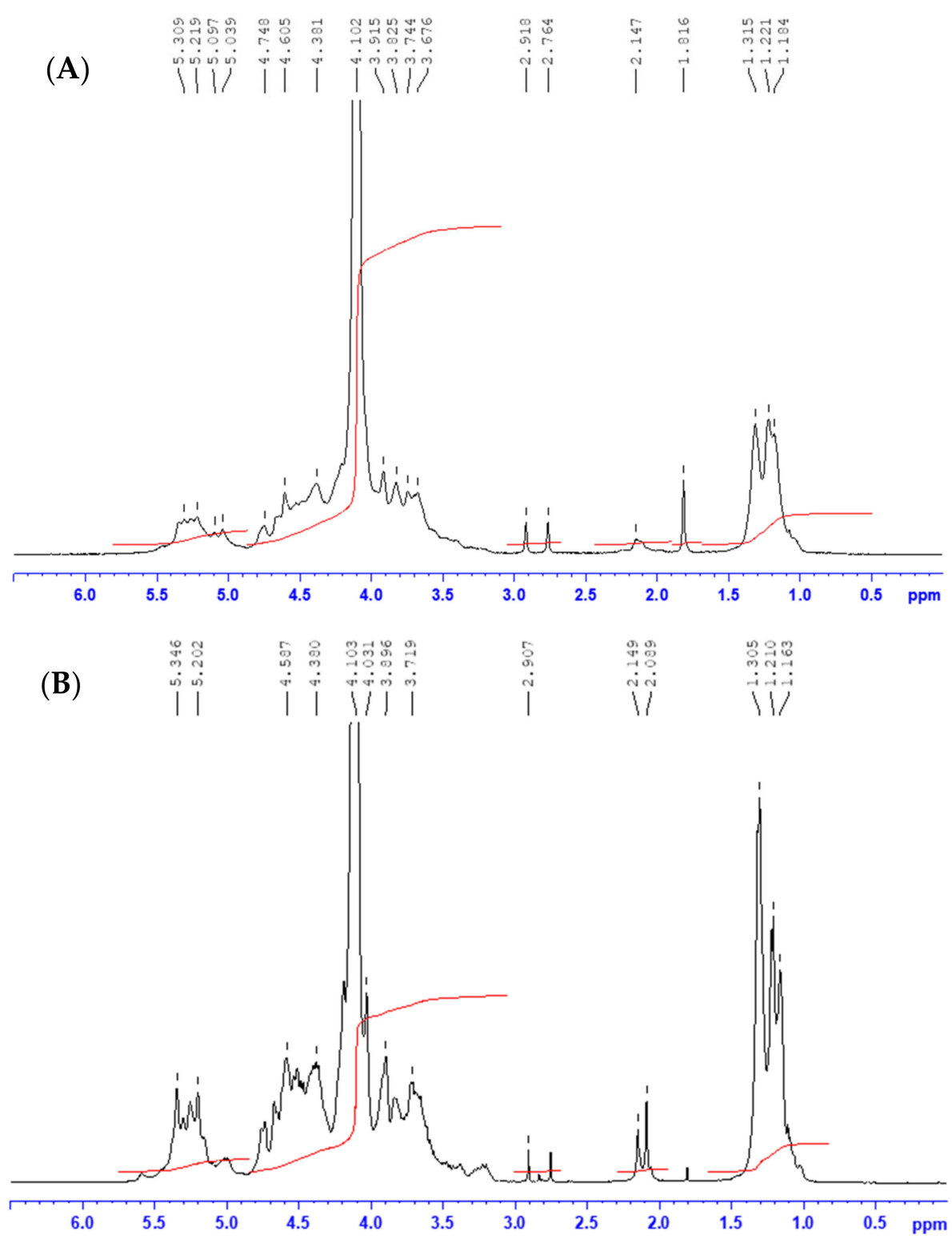

Figure 1. ${ }^{1} \mathrm{H}$ NMR spectra of sulfated polysaccharides from (A) B. bifurcata $(\mathrm{BBF})$ and $($ B) F. spiralis (FSF) at $60{ }^{\circ} \mathrm{C}$ in $\mathrm{D}_{2} \mathrm{O}$ solution.

\subsection{Effect of Fucoidans (FSF and BBF) on the Natural Defence of Date Palm Roots}

\subsubsection{Phenylalanine Amonia-Lyase (PAL) Activity}

Given the involvement of the phenolic metabolism in the natural defenses in date palm roots against Foa [17], the mobilization of the phenlypropanoids pathway was demonstrated by studying PAL activity, as the main enzyme of this metabolic pathway. As shown in Figure 3, PAL activity was induced by both $F$. spiralis (FSF) and B. bifurcata (BBF) fucoidans. A total of $12 \mathrm{~h}$ of FSF treatment were sufficient to significantly increase PAL activity compared to the control treatment $(p<0.05)$. This increase stayed significantly different from control plants over $24 \mathrm{~h}$. A second narrower peak was obtained at $96 \mathrm{~h}$, this could be explained by the elicitor solutions (fucoidans) remained in permanent contact with the roots for the duration of the experiment (4 days), leading to a second wave of induction 
of PAL activity. The BBF treatment intensely and significantly increased PAL activity after $24 \mathrm{~h}$ of treatment, 4.8 times higher than the response noted in control plants $(p<0.05)$.

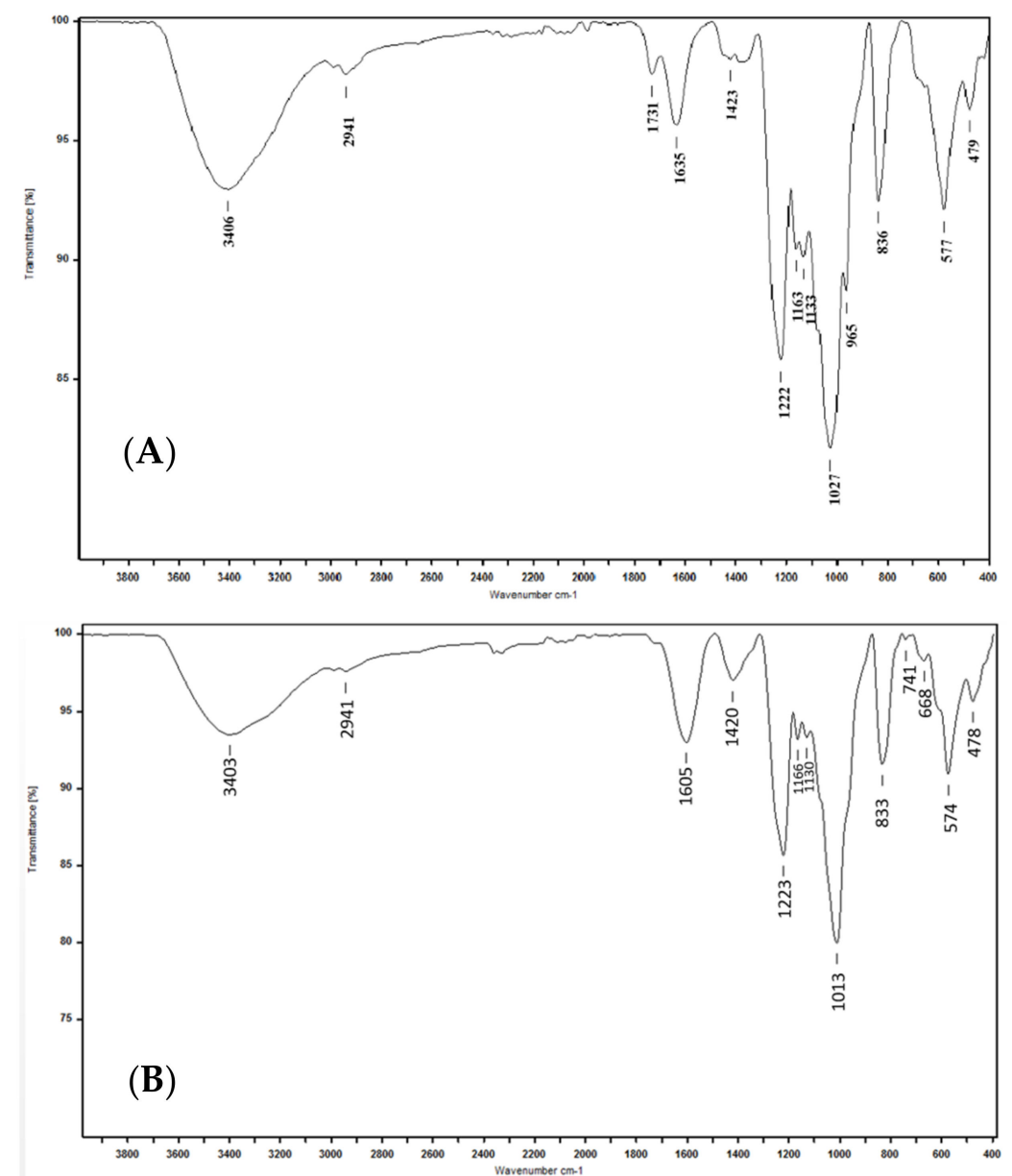

Figure 2. ATR-FTIR spectra of sulfated polysaccharides from (A) B. bifurcata (BBF) and (B) F. spiralis (FSF).

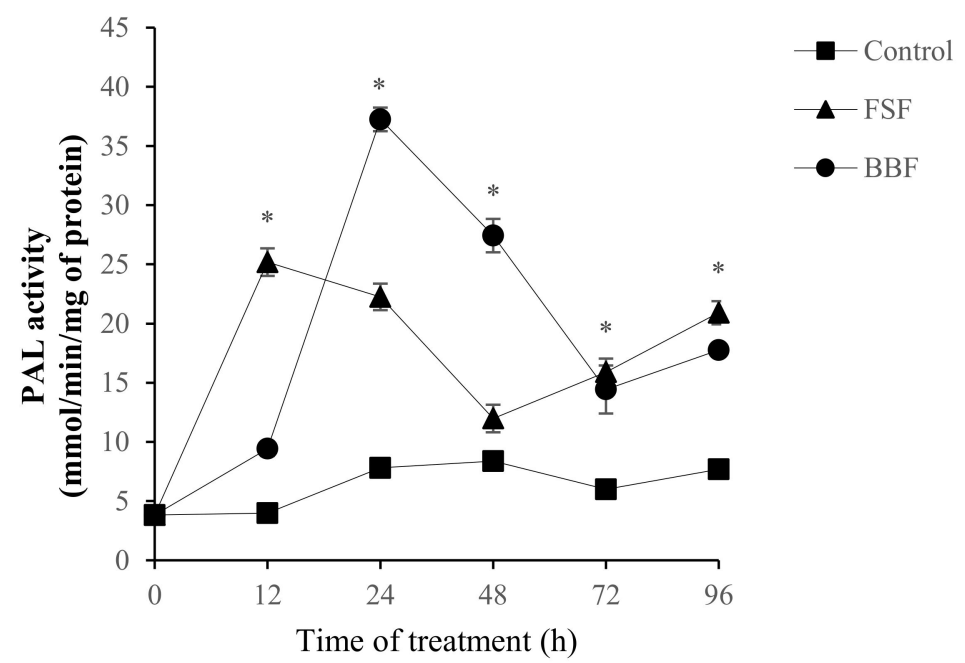

Figure 3. Induction of phenylalanine ammonia-lyase (PAL) activity in date palm roots treated with sulfated polysaccharides of F. spiralis (FSF) and B. bifurcata (BBF). Based on Tukey's test at $12 \mathrm{~h}, 24 \mathrm{~h}$, $72 \mathrm{~h}$ and $96 \mathrm{~h}{ }^{*}$ Control vs. FSF: $p<0.05$, at $24 \mathrm{~h}, 48 \mathrm{~h}, 72 \mathrm{~h}$ and $96 \mathrm{~h}{ }^{*}$ Control vs. BBF: $p<0.05$. 


\subsubsection{Total Phenolic Compounds Content}

The elicitor effect of the sulfated polysaccharides studied (FSF and BBF) on phenolic metabolism was also approached by the accumulation of total phenols in treated roots. The accumulation of phenolic compounds following FSF and BBF treatments was presented in Figure 4. Roots elicitation by FSF caused a significant $(p<0.05)$ and intense accumulation of phenolic compounds after $24 \mathrm{~h}$ compared to the control treatment (Figure 4). Second narrower accumulation of phenols was approved after $72 \mathrm{~h}$ of FSF treatment, this could be explained by the induction of PAL activity at the same time. However, a precocious and significant $(p<0.05)$ accumulation of these compounds was manifested just $12 \mathrm{~h}$ after following BBF treatment, this level of phenolic compounds remained higher than control plants during $24 \mathrm{~h}$ before decreasing at $48 \mathrm{~h}$.

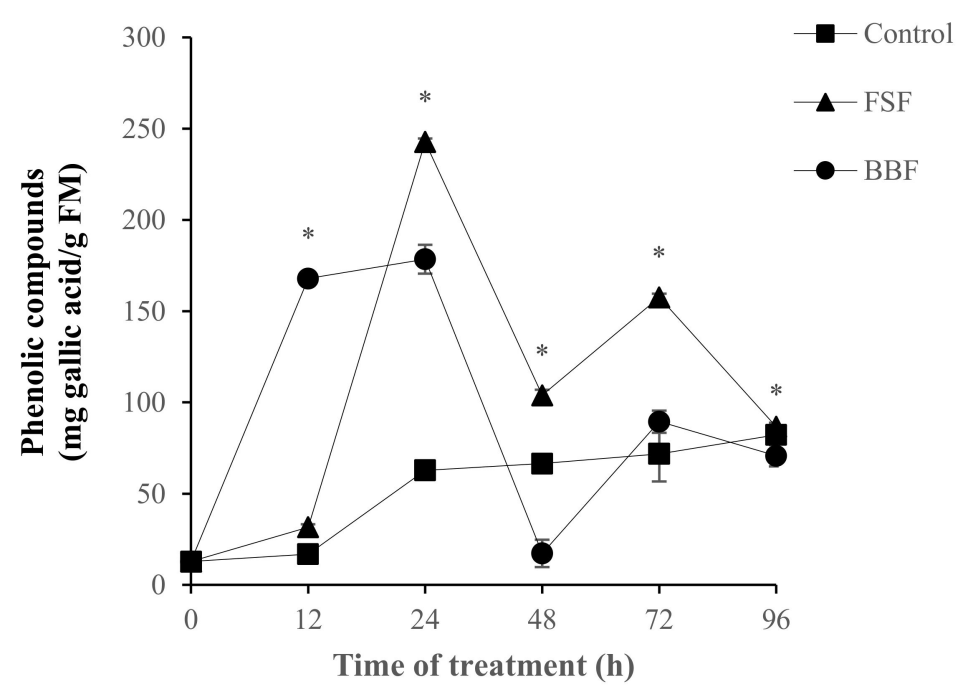

Figure 4. Effect of F. spiralis (FSF) and B. bifurcata (BBF) fucoidans on the accumulation of phenolic compounds in date palm roots. Means values \pm SE. Based on Tukey's test at $12 \mathrm{~h}$ and $24 \mathrm{~h} *$ Control vs. BBF: $p<0.05$, at $24 \mathrm{~h}, 48 \mathrm{~h}$ and $72 \mathrm{~h} *$ Control vs. FSF: $p<0.05$.

\subsubsection{Accumulation of Lignin Content}

Different trend of the lignin deposition in treated roots was exhibited following elicitation by FSF and BBF (Figure 5). The level of this metabolite increased slightly after $12 \mathrm{~h}$ then greatly increased $(p<0.05)$ after $48 \mathrm{~h}$ of FSF treatment. This response was expected since lignin is a phenols polymer whose maximum accumulation was obtained after $24 \mathrm{~h}$ with FSF (Figure 4 ). On the other hand, with BBF treatment (Figure 5), the lignin contents undergo a weak increase after $24 \mathrm{~h}$ and $48 \mathrm{~h}$ of elicitation while after $96 \mathrm{~h}$ a higher increase was noted, this could be explained by the possibility of the polymerization of phenolic compounds increased after $72 \mathrm{~h}$ of BBF treatment. The highest content of lignin was obtained at $48 \mathrm{~h}$ in response to FSF and after $96 \mathrm{~h}$ of BBF treatment, it is three times higher than that obtained in control roots.

The crude fucoidans from $F$. spiralis (FSF) and B. bifurcata (BBF) were extracted and structurally characterized; the results obtained show a significant proportion of L-fucose in FSF and BBF with a higher degree of sulfation ( 45 and $49 \% w / w$ respectively). A biological test showed that the crude fucoidans (FSF and BBF) exhibit an eliciting effect of the defence mechanisms in date palm roots. These mechanisms were initiated by the induction of PAL activity. FSF and BBF expressed a slightly differential effect on PAL activity, which could be due to the difference in structure between the two fucoidans. Indeed, the structural characterization revealed differences in sulfate proportions within FSF and BBF, suggesting a difference in FSF and BBF affinity to membrane receptors. The perception and recognition of elicitors from pathogens, plants and algae called damage- or pathogen-associated molecular pattern molecules (DAMPs, PAMPs) by Pattern Recognition Receptors (PRRs) in plants 
induces a signalling cascade in the host cell through their cytosolic domains leading to the induction of defence mechanisms in the host plant [39]. This could be the cause of the early induction of PAL activity after treatment with FSF compared to BBF. In addition, following the induction of PAL activity, the phenolic metabolites were accumulated in the treated roots, as well as lignin deposition. Phenols and lignin are among the most involved defence elements during date palm-Foa interactions [15-20]. The results obtained are similar to the reaction observed in tobacco plants pretreated with fucoidans and sulfated oligofucoidans, in which PAL activity was also induced [14]. In addition, such tobaccos demonstrate an increase in the activity of lipoxygenase (LOX) and Pathogenesis-related protein (PR), as well as transient defence reactions such as acidification of the cytoplasm and accumulation of $\mathrm{H}_{2} \mathrm{O}_{2}$ [14]. Based on this, it is possible to assume similar effects in the case of date palm root response to FSF and $\mathrm{BBF}$, including also the induction of glutathione-S-transferase (GST) activity, as shown for tobacco [15]. In addition, a fucoidans pre-treatment of carrot leaves protects them against Alternaria radicina and Botrytis cinerea attacks by stimulating the accumulation of phenolic compounds and by inducing peroxidase (POD) and polyphenol oxidase (PPO) activities [40]. Thus, fucoidans-treated date palm roots, besides phenolic compounds accumulation, may also activate the POD and PPO enzymes. Otherwise, we have shown in recent work, that alginates extracted from the same brown algae $F$. spiralis and B. bifurcata stimulate the natural defenses of date palm in the same way as fucoidans, but the latter seem to be more active at low concentrations $(0.5 \mathrm{~g} / \mathrm{L})$ compared to $1 \mathrm{~g} / \mathrm{L}$ of alginates [41]. This could be explained by the structural difference between alginates and fucoidans, in particular the presence of sulfated groups and the degree of sulfation. The structure-function relationship governing the induction of plant defence mechanisms in response to fucoidans stile less elucidated. However it was reported that sulfation of polysaccharides alters their affinity for receptors located in cell walls [42]. In addition, the desulfation of sulfated polysaccharides reduces or eliminates their eliciting effect on natural defenses in tomatoes [43], whereas oligo-carrageenans $(\lambda)$ with a higher degree of sulfation reduce the impact of various viral, bacterial and fungal diseases [44]. Furthermore a sulfated ulvan and oligo-ulvans improve the induction of PAL activity and therefore the accumulation of the phenols in tomato leaves [43], apple fruit [3] and olive tree [45]. Numerous works on the other biological activities of fucoidans relate their effectiveness to their structural characteristics, notably sulfation and molecular weight. It has been widely documented that fucoidans owe their broad spectrum of biological activities to their sulfated nature and molecular weights $[6,27,28,46,47]$. Based on previous work, fucoidans with a molecular weight $(\mathrm{Mw})$ between 10 and $300 \times 10^{3} \mathrm{~g} /$ mole showed significant anticoagulant activity than those with higher $\mathrm{Mw}>850 \times 10^{3} \mathrm{~g} /$ mole [48-50]. Likewise, immune-regulation activities increased with low molecular weight fucoidans of Laminaria japonica [51]. It has been shown also that the immune-regulatory potential of fucoidan was influenced by the sulfate group as well as the acetyl one [52]. In short, the biological efficiency of fucoidans was modulated by several parameters, in particular the proportion of $\mathrm{SO}_{4}{ }^{2-}$ groups and their position, the molecular weight, the acetylation degree and monosaccharides composition [6,53]. 


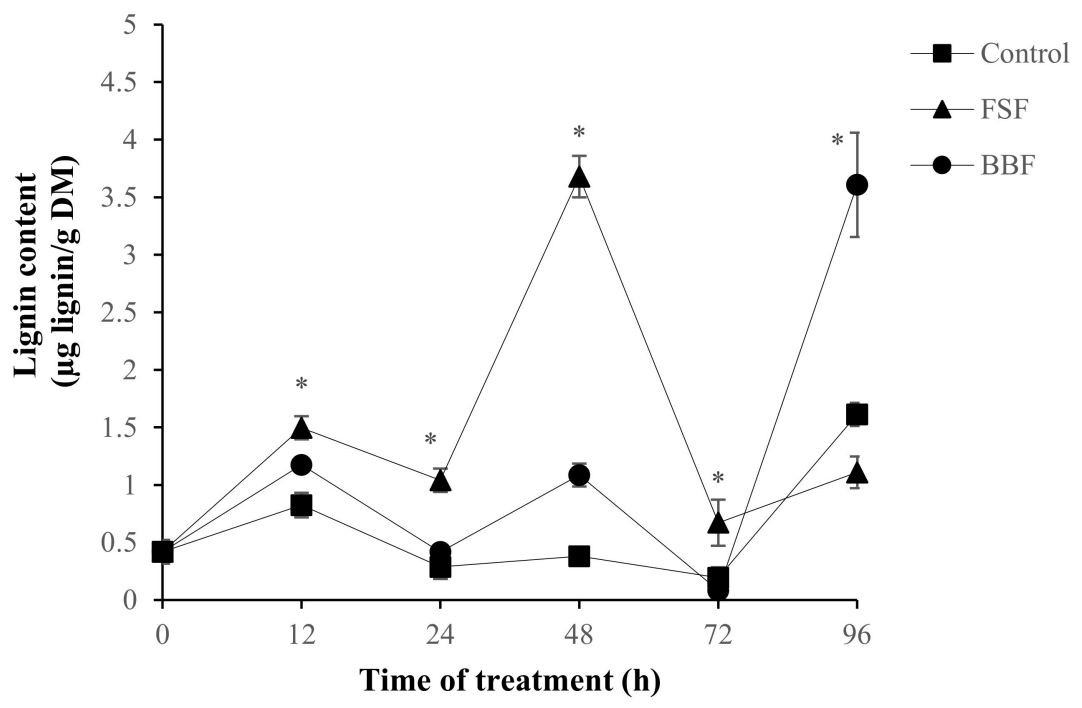

Figure 5. Effect of sulfated polysaccharides from F. spiralis (FSF) and B. bifurcata (BBF) on the accumulation of lignin in date palm roots. Means values \pm SE. Based on Tukey's test at $12 \mathrm{~h}, 24 \mathrm{~h}, 48 \mathrm{~h}$ and $72 \mathrm{~h} *$ Control vs. FSF: $p<0.05$, at $12 \mathrm{~h}, 48 \mathrm{~h}$ and $96 \mathrm{~h}{ }^{*}$ Control vs. BBF: $p<0.05$.

\section{Conclusions}

The crude fucoidans from the brown algae, F. spiralis and B. bifurcata tested on the date palm roots, display potential elicitor activity on the phenolic metabolism due to the induction of PAL activity. Thus, leading to mobilisation of the phenlypropanoids pathway and to the accumulation of phenolic compounds and lignin. The elicitor effect of studied fucoidans was related to their highly sulfated structures with a small molecular weight $\left(M_{\mathrm{W}}\right)$. In addition, the simple and innovative elicitation model adopted in this paper highlighted the elicitor effect of fucoidans without stressing the roots, which could be applied in the field. These results open prospects for the formulation of a biological product, leading to a preventive control of date palm Bayoud disease.

\section{Materials and Methods}

\subsection{Extraction, Purification and Chemical Analysis of Fucoidans (FSF and BBF)}

Brown algae B. bifurcata and F. spiralis were harvested on the at El Jadida city (Morocco) in December 2017. The extraction and separation of sulfated polysaccharides were performed according to Ermakova et al. [54]. Samples of $25 \mathrm{~g}$ of each algae species were depigmented with formaldehyde $2 \%$ and then dried for $12 \mathrm{~h}$ at ambient temperature. Dried powders were then treated twice with $\mathrm{HCl}$ $0.1 \mathrm{M}$ solution during $2 \mathrm{~h}\left(\right.$ at $\left.60{ }^{\circ} \mathrm{C}, 450 \mathrm{rpm}\right)$. After centrifugation for $20 \mathrm{~min}$ at $5000 \mathrm{rpm}$, the recovered supernatants were neutralized to $\mathrm{pH}$ 7.5. Crude fucoidans were obtained with thrice ethanol $96 \%$ $(3 v / v)$ precipitation and then freeze-dried to B. bifurcata and $F$. spiralis crude fucoidans powders (BBF and FSF, respectively). All chemical analysis of FSF and BBF was performed using colorimetric assays as described in previous paper [41].

\subsection{GC-MS Analysis of FSF and BBF}

Prior to GC-MS analysis, samples of $15 \mathrm{mg}$ of BBF and FSF were hydrolyzed using Trifluoroacetic acid (TFA) under $120{ }^{\circ} \mathrm{C}$ for $90 \mathrm{~min}$. Monosaccharides generated by this acid hydrolysis were then treated with N,O-Bis (trimethylsilyl) trifluoroacetamide (BSTFA) with 1\% Trimethylchlorosilane (TMCS) according to Pierre et al.'s method [55,56]. After evaporation, monosaccharides constituting the fucoidans (FSF and BBF) as well as the standards were injected in GC-MS at $10 \mathrm{~g} / \mathrm{L}$ of dichloromethne. 


\subsection{ATR-FTIR Spectroscopy}

Infrared analysis of FSF and BBF was carried out using the Attenuated Total Reflectance (ATR) technique by a VERTEX 70 FTIR system. Spectra were obtained after $50 \mathrm{scans}$ in a $500-400 \mathrm{~cm}^{-1}$ wave range.

\section{4. ${ }^{1} H$ NMR Spectroscopy Analysis}

Twenty mg of crude fucoidans was prepared thrice in $0.5 \mathrm{~mL}$ of $\mathrm{D}_{2} \mathrm{O}$. With a $400 \mathrm{MHz}$ Bruker AVANCE spectrometer, the ${ }^{1} \mathrm{H}$ NMR spectroscopy analysis was carried out at $60{ }^{\circ} \mathrm{C}$.

\subsection{Elicitation Test}

Roots of three-month-old date palm plants (greenhouse model) were soaked in fucoidan solutions (FSF and BBF) at a concentration of $0.5 \mathrm{~g} / \mathrm{L}$ and $\mathrm{pH} 6.5$ over 4 days. Fucoidans-treated roots were compared to distilled water-treated roots as a control treatment. After $12 \mathrm{~h}$ and then every $24 \mathrm{~h}$, biochemical assays of phenylalanine ammonialyase (PAL) activity, phenolic compounds and lignin content in treated roots were performed. Data were reported as the means values of 3 replicates, each replicate containing 3 plants.

\subsection{Phenylalanine Ammonialyase (PAL) Activity}

PAL activity was determined according to the method described by Liu et al. [57] with slight modifications. Enzyme extract was prepared at $4{ }^{\circ} \mathrm{C}$, with $250 \mathrm{mg}$ of crushed date palm roots in $3 \mathrm{~mL}$ of borate buffer $\left(100 \mathrm{mM}, \mathrm{pH} 8.8,4^{\circ} \mathrm{C}\right)$ with EDTA $(1 \mathrm{mM})$ and $5 \%(w / v)$ of insoluble polyvinyl polypyrrolidone (PVPP). The enzyme extract was recovered after centrifugation for $30 \mathrm{~min}$ and at $10,000 \times g$. The reaction mixture of PAL activity assay composed of enzymatic extract $(600 \mu \mathrm{L})$, L-phenylalanine at $20 \mathrm{mM}(250 \mu \mathrm{L})$ and borate buffer $(1 \mathrm{~mL})$. An amount of $100 \mu \mathrm{L} \mathrm{HCl}$ was added after incubation $\left(1 \mathrm{~h}, 30^{\circ} \mathrm{C}\right)$. The results were obtained at $920 \mathrm{~nm}$. The Bradford method [58] was then used to quantify the total protein in the enzyme extract.

\subsection{Phenolic Compounds}

The hydromethanolic phenolic extracts obtained according to Hagen et al.'s [59] method were then purified using the protocol described in previous paper [41]. Total phenolic determination was performed following the Folin-Ciocalteu method [60].

\subsection{Extraction and Spectrophotometric Assay of Lignin Content}

The lignin was extracted using the Bruce and West [61] protocol, with some modifications, in $0.5 \mathrm{~mL}$ of ethanol $90 \%(v / v)$, were grounded $500 \mathrm{mg}$ of treated roots. Pellet obtained after centrifugation at $10,000 \times \mathrm{g}$ for $20 \mathrm{~min}$ and at $4{ }^{\circ} \mathrm{C}$ was dried for $12 \mathrm{~h}$ at $35^{\circ} \mathrm{C}$. Samples of $25 \mathrm{mg}$ of the dried residue were treated with $0.5 \mathrm{~mL}$ of thioglycolic acid and $1.25 \mathrm{~mL}$ of $\mathrm{HCl}$ solution at $2 \mathrm{M}$. The mixture was heated during $8 \mathrm{~h}$ at $100^{\circ} \mathrm{C}$. After cooling and centrifugation, $2.5 \mathrm{~mL}$ of $\mathrm{NaOH}$ was added to the pellet. The supernatant recovered after stirring for $18 \mathrm{~h}$ at $25^{\circ} \mathrm{C}$, was centrifuged $\left(10,000 \times g, 20 \mathrm{~min}, 4{ }^{\circ} \mathrm{C}\right)$ treated with $0.5 \mathrm{~mL}$ of pure $\mathrm{HCl}$, to precipitate lignin thioglycolic acid after incubation over $4 \mathrm{~h}$ at $4{ }^{\circ} \mathrm{C}$. The absorbance at $280 \mathrm{~nm}$ was measured in $500 \mu \mathrm{L}$ of $\mathrm{NaOH}$. The lignin content was expressed in $\mu \mathrm{g}$ of lignin thioglycolic acid/g Dry Matter (DM).

\subsection{Statistical Analysis}

PAL activity, polyphenols and lignin contents results were tested by ANOVA analysis in SPSS software Version 20.0 using Tukey's test. The difference between treatments is significant at $p<0.05$. 
Author Contributions: Conceptualization, S.B., C.D., Z.E.A.-T. and C.E.M.; methodology, S.B., G.P., and. Z.E.A.-T.; supervision, C.D., C.E.M., and Z.E.A.-T.; Software, S.B.; Validation, S.B., C.D., Z.E.A.-T. and C.E.M.; writing-Original draft, S.B., C.D., Z.E.A.-T., and C.E.M., writing-Review and editing, S.B., C.D., Z.E.A.-T.; C.E.M, G.P., H.R., and P.M. All authors have read and agreed to the published version of the manuscript.

Funding: This research was funded by Hubert Curien Program (PHC TOUBKAL 18/63), and financially supported by Ministry of Europe and Foreign Affairs, and CNRST of Morocco within the French-Morocco bilateral program. Grant Number: 38964TM.

Conflicts of Interest: The authors declare no conflict of interest.

\section{References}

1. Wijesinghe, W.; Jeon, Y.-J. Biological activities and potential industrial applications of fucose rich sulfated polysaccharides and fucoidans isolated from brown seaweeds: A review. Carbohydr. Polym. 2012, 88, 13-20. [CrossRef]

2. Prajapati, V.D.; Maheriya, P.M.; Jani, G.K.; Solanki, H.K. Carrageenan: A natural seaweed polysaccharide and its applications. Carbohydr. Polym. 2014, 105, 97-112. [CrossRef]

3. Abouraïcha, E.; Alaoui-Talibi, Z.E.; Boutachfaiti, R.E.; Petit, E.; Courtois, B.; EL Modafar, C. Induction of natural defense and protection against Penicillium expansum and Botrytis cinerea in apple fruit in response to bioelicitors isolated from green algae. Sci. Hortic. 2015, 181, 121-128. [CrossRef]

4. Berteau, O. Sulfated fucans, fresh perspectives: structures, functions, and biological properties of sulfated fucans and an overview of enzymes active toward this class of polysaccharide. Glycobiology 2003, 13, 29R-40R. [CrossRef]

5. Bouissil, S.; Pierre, G.; El Alaoui-Talibi, Z.; Michaud, P.; El Modafar, C.; Delattre, C. Applications of Algal Polysaccharides and Derivatives in Therapeutic and Agricultural Fields. Curr. Pharm. Des. 2019, 25, 1187-1199. [CrossRef]

6. Wang, Y.; Xing, M.; Cao, Q.; Ji, A.; Liang, H.; Song, S. Biological Activities of Fucoidan and the Factors Mediating Its Therapeutic Effects: A Review of Recent Studies. Mar. Drugs 2019, 17, 183. [CrossRef]

7. Yuan, Y.; MacQuarrie, D.J. Microwave assisted extraction of sulfated polysaccharides (fucoidan) from Ascophyllum nodosum and its antioxidant activity. Carbohydr. Polym. 2015, 129, 101-107. [CrossRef] [PubMed]

8. Sellimi, S.; Kadri, N.; Barragan-Montero, V.; Laouer, H.; Mohamed, H.; Nasri, M. Fucans from a Tunisian brown seaweed Cystoseira barbata: Structural characteristics and antioxidant activity. Int. J. Biol. Macromol. 2014, 66, 281-288. [CrossRef]

9. Li, S.; Gao, A.; Dong, S.; Chen, Y.; Sun, S.; Lei, Z.; Zhang, Z. Purification, antitumor and immunomodulatory activity of polysaccharides from soybean residue fermented with Morchella esculenta. Int. J. Biol. Macromol. 2017, 96, 26-34. [CrossRef]

10. Mori, N.; Takeda, K.; Tomimori, K.; Kimura, R.; Ishikawa, C.; Nowling, T.K. Anti-tumor activity of fucoidan is mediated by nitric oxide released from macrophages. Int. J. Oncol. 2011, 40, 251-260. [CrossRef]

11. Park, H.S.; Kim, G.-Y.; Nam, T.-J.; Kim, N.D.; Choi, Y.H. Antiproliferative Activity of Fucoidan Was Associated with the Induction of Apoptosis and Autophagy in AGS Human Gastric Cancer Cells. J. Food Sci. 2011, 76, T77-T83. [CrossRef]

12. Park, H.Y.; Park, S.-H.; Jeong, J.-W.; Yoon, D.; Han, M.H.; Lee, D.-S.; Choi, G.; Yim, M.-J.; Lee, J.M.; Kim, D.-H.; et al. Induction of p53-Independent Apoptosis and G1 Cell Cycle Arrest by Fucoidan in HCT116 Human Colorectal Carcinoma Cells. Mar. Drugs 2017, 15, 154. [CrossRef] [PubMed]

13. Athukorala, Y.; Jung, W.-K.; Vasanthan, T.; Jeon, Y.-J. An anticoagulative polysaccharide from an enzymatic hydrolysate of Ecklonia cava. Carbohydr. Polym. 2006, 66, 184-191. [CrossRef]

14. Klarzynski, O.; Descamps, V.; Plesse, B.; Yvin, J.-C.; Kloareg, B.; Fritig, B. Sulfated Fucan Oligosaccharides Elicit Defense Responses in Tobacco and Local and Systemic Resistance against Tobacco Mosaic Virus. Mol. Plant Microbe Interact. 2003, 16, 115-122. [CrossRef] [PubMed]

15. Chandía, N.; Matsuhiro, B. Characterization of a fucoidan from Lessonia vadosa (Phaeophyta) and its anticoagulant and elicitor properties. Int. J. Biol. Macromol. 2008, 42, 235-240. [CrossRef]

16. Klarzynski, O.; Plesse, B.; Joubert, J.-M.; Yvin, J.-C.; Kopp, M.; Kloareg, B.; Fritig, B. Linear $\beta-1,3$ Glucans Are Elicitors of Defense Responses in Tobacco. Plant Physiol. 2000, 124, 1027-1038. [CrossRef] 
17. EL Modafar, C. Mechanisms of date palm resistance to Bayoud disease: Current state of knowledge and research prospects. Physiol. Mol. Plant Pathol. 2010, 74, 287-294. [CrossRef]

18. EL Modafar, C.; Tantaoui, A.; Boustani, E.E. Cinetique d'accumulation et Fongitoxicite des Phytoalexines du Palmier Dattier vis-a-vis de Fusarium oxysporum f. sp. albedinis. J. Phytopathol. 1999, 147, 477-484. [CrossRef]

19. Ziouti, A.; EL Modafar, C.; Fleuriet, A.; Boustani, S.E.; Macheix, J. Les polyphénols, marqueurs potentiels de la résistance du palmier dattier (Phoenix dactylifera L.) au Fusarium oxysporum f. sp. albedinis. Compte rendu du Groupe Polyphénols. J. Nat. Prod. 1992, 16, 346-349.

20. Kidder, G.W.; Awayda, M.S.; Iii, G.W.K. Effects of azide on gastric mucose. Biochim. Biophys. Acta Bioenerg. 1989, 973, 59-66. [CrossRef]

21. EL Modafar, C.; Boustani, E.E. Cell Wall-Bound Phenolic Acid and Lignin Contents in Date Palm as Related to its Resistance to Fusarium Oxysporum. Biol. Plant. 2001, 44, 125-130. [CrossRef]

22. EL Modafar, C.; Tantaoui, A.; Boustani, E.-S.E. Differential induction of phenylalanine ammonia-lyase activity in date palm roots in response to inoculation with Fusarium oxysporum $\mathrm{f}$. sp. albedinis and to elicitation with fungal wall elicitor. J. Plant Physiol. 2001, 158, 715-722. [CrossRef]

23. Mian, A.; Percival, E. Carbohydrates of the brown seaweeds himanthalia lorea, bifurcaria bifurcata, and Padina pavonia. Carbohydr. Res. 1973, 26, 133-146. [CrossRef]

24. Hentati, F.; Delattre, C.; Ursu, A.V.; Desbrières, J.; Le Cerf, D.; Gardarin, C.; Abdelkafi, S.; Michaud, P.; Pierre, G. Structural characterization and antioxidant activity of water-soluble polysaccharides from the Tunisian brown seaweed Cystoseira compressa. Carbohydr. Polym. 2018, 198, 589-600. [CrossRef]

25. Ammar, H.H.; Hafsa, J.; Cerf, D.L.; Bouraoui, A.; Majdoub, H. Antioxidant and gastroprotective activities of polysaccharides from the Tunisian brown algae (Cystoseira sedoides). J. Tunis. Chem. Soc. 2016, 18, 80-88.

26. Rabanal, M.; Ponce, N.M.; Navarro, D.A.; Gómez, R.M.; Stortz, C.A. The system of fucoidans from the brown seaweed Dictyota dichotoma: Chemical analysis and antiviral activity. Carbohydr. Polym. 2014, 101, 804-811. [CrossRef]

27. Prokofjeva, M.M.; Imbs, T.; Shevchenko, N.M.; Spirin, P.V.; Horn, S.; Fehse, B.; Zvyagintseva, T.; Prassolov, V.S. Fucoidans as Potential Inhibitors of HIV-1. Mar. Drugs 2013, 11, 3000-3014. [CrossRef]

28. Vishchuk, O.S.; Tarbeeva, D.V.; Ermakova, S.P.; Zvyagintseva, T.N. Structural Characteristics and Biological Activity of Fucoidans from the Brown Algae Alaria sp. and Saccharina japonica of Different Reproductive Status. Chem. Biodivers. 2012, 9,817-828. [CrossRef]

29. Malyarenko, O.S.; Ermakova, S.; Zvyagintseva, T.N. Sulfated polysaccharides from brown seaweeds Saccharina japonica and Undaria pinnatifida: isolation, structural characteristics, and antitumor activity. Carbohydr. Res. 2011, 346, 2769-2776. [CrossRef]

30. Cho, M.; Lee, D.-J.; Kim, J.-K.; You, S. Molecular characterization and immunomodulatory activity of sulfated fucans from Agarum cribrosum. Carbohydr. Polym. 2014, 113, 507-514. [CrossRef]

31. Saha, S.; Navid, M.H.; Bandyopadhyay, S.S.; Schnitzler, P.; Ray, B. Sulfated polysaccharides from Laminaria angustata: Structural features and in vitro antiviral activities. Carbohydr. Polym. 2012, 87, 123-130. [CrossRef]

32. Synytsya, A.; Kim, W.-J.; Kim, S.-M.; Pohl, R.; Synytsya, A.; Kvasnička, F.; Čopíková, J.; Park, Y.I. Structure and antitumour activity of fucoidan isolated from sporophyll of Korean brown seaweed Undaria pinnatifida. Carbohydr. Polym. 2010, 81, 41-48. [CrossRef]

33. Pereira, M.S.; Mulloy, B.; Mourão, P.A.S. Structure and Anticoagulant Activity of Sulfated Fucans. J. Biol. Chem. 1999, 274, 7656-7667. [CrossRef]

34. Kariya, Y.; Mulloy, B.; Imai, K.; Tominaga, A.; Kaneko, T.; Asari, A.; Suzuki, K.; Masuda, H.; Kyogashima, M.; Ishii, T. Isolation and partial characterization of fucan sulfates from the body wall of sea cucumber Stichopus japonicus and their ability to inhibit osteoclastogenesis. Carbohydr. Res. 2004, 339, 1339-1346. [CrossRef] [PubMed]

35. Benaoun, F.; Delattre, C.; Boual, Z.; Ursu, A.V.; Vial, C.; Gardarin, C.; Wadouachi, A.; Le Cerf, D.; Varacavoudin, T.; El-Hadj, M.D.O.; et al. Structural characterization and rheological behavior of a heteroxylan extracted from Plantago notata Lagasca (Plantaginaceae) seeds. Carbohydr. Polym. 2017, 175, 96-104. [CrossRef]

36. Dammak, M.; Hadrich, B.; Miladi, R.; Barkallah, M.; Hentati, F.; Hachicha, R.; Laroche, C.; Michaud, P.; Fendri, I.; Abdelkafi, S. Effects of nutritional conditions on growth and biochemical composition of Tetraselmis sp. Lipids Health Dis. 2017, 16, 41. [CrossRef] 
37. Sekkal, M.; Legrand, P. A spectroscopic investigation of the carrageenans and agar in the $1500-100 \mathrm{~cm}^{-1}$ spectral range. Spectrochim. Acta Part A Mol. Spectrosc. 1993, 49, 209-221. [CrossRef]

38. Dore, C.M.P.G.; Alves, M.G.D.C.F.; Will, L.S.E.P.; Costa, T.G.; Sabry, D.A.; Rêgo, L.A.R.D.S.; Accardo, C.M.; Rocha, H.A.O.; Filgueira, L.G.A.; Leite, E.L. A sulfated polysaccharide, fucans, isolated from brown algae Sargassum vulgare with anticoagulant, antithrombotic, antioxidant and anti-inflammatory effects. Carbohydr. Polym. 2013, 91, 467-475. [CrossRef]

39. Lotze, M.T.; Zeh, H.J.; Rubartelli, A.; Sparvero, L.J.; Amoscato, A.A.; Washburn, N.R.; Devera, M.E.; Liang, X.; Tör, M.; Billiar, T. The grateful dead: damage-associated molecular pattern molecules and reduction/oxidation regulate immunity. Immunol. Rev. 2007, 220, 60-81. [CrossRef]

40. Jayaraj, J.; Wan, A.; Rahman, M.; Punja, Z.K. Seaweed extract reduces foliar fungal diseases on carrot. Crop. Prot. 2008, 27, 1360-1366. [CrossRef]

41. Bouissil, S.; El Alaoui-Talibi, Z.; Pierre, G.; Michaud, P.; El Modafar, C.; Delattre, C. Use of Alginate Extracted from Moroccan Brown Algae to Stimulate Natural Defense in Date Palm Roots. Molecules 2020, $25,720$. [CrossRef] [PubMed]

42. Ménard, R.; De Ruffray, P.; Fritig, B.; Yvin, J.-C.; Kauffmann, S. Defense and Resistance-inducing Activities in Tobacco of the Sulfated $\beta-1,3$ glucan PS3 and its Synergistic Activities with the Unsulfated Molecule. Plant Cell Physiol. 2005, 46, 1964-1972. [CrossRef]

43. Modafar, C.E.; Elgadda, M.; Boutachfaiti, R.E.; Abouraicha, E.; Zehhar, N.; Petit, E.; Alaoui-Talibi, Z.E.; Courtois, B.; Courtois, J. Induction of natural defence accompanied by salicylic acid-dependant systemic acquired resistance in tomato seedlings in response to bioelicitors isolated from green algae. Sci. Hortic. 2012, 138, 55-63. [CrossRef]

44. Vera, J.; Castro, J.; Contreras, R.A.; González, A.; Moenne, A. Oligo-carrageenans induce a long-term and broad-range protection against pathogens in tobacco plants (var. Xanthi). Physiol. Mol. Plant Pathol. 2012, 79, 31-39. [CrossRef]

45. Ben Salah, I.; Aghrouss, S.; Douira, A.; Aissam, S.; El Alaoui-Talibi, Z.; Filali-Maltouf, A.; El Modafar, C. Seaweed polysaccharides as bio-elicitors of natural defenses in olive trees against verticillium wilt of olive. J. Plant Interact. 2018, 13, 248-255. [CrossRef]

46. Ale, M.T.; Mikkelsen, J.D.; Meyer, A.S. Important Determinants for Fucoidan Bioactivity: A Critical Review of Structure-Function Relations and Extraction Methods for Fucose-Containing Sulfated Polysaccharides from Brown Seaweeds. Mar. Drugs 2011, 9, 2106-2130. [CrossRef] [PubMed]

47. Wells, M.L.; Potin, P.; Craigie, J.S.; Raven, J.A.; Merchant, S.S.; Helliwell, K.E.; Smith, A.G.; Camire, M.E.; Brawley, S.H. Algae as nutritional and functional food sources: revisiting our understanding. Environ. Biol. Fishes 2016, 29, 949-982. [CrossRef]

48. Shanmugam, M.; Mody, K. Heparinoid-active sulphated polysaccharides from marine algae as potential blood anticoagulant agents. Curr. Sci. India 2000, 79, 1672-1683.

49. Zayed, A.; Hahn, T.; Rupp, S.; Kramer, R.; Ulber, R. Fucoidan as a natural anticoagulant, antiviral and anti-cancer drug. Naunyn Schmiedebergs Arch. Pharmacol. 2018, 391, S7-S8.

50. Yang, C.; Chung, D.; Shin, I.-S.; Lee, H.; Kim, J.; Lee, Y.; You, S. Effects of molecular weight and hydrolysis conditions on anticancer activity of fucoidans from sporophyll of Undaria pinnatifida. Int. J. Biol. Macromol. 2008, 43, 433-437. [CrossRef]

51. Sun, T.; Zhang, X.; Miao, Y.; Zhou, Y.; Shi, J.; Yan, M.; Chen, A. Studies on Antiviral and Immuno-Regulation Activity of Low Molecular Weight Fucoidan from Laminaria japonica. J. Ocean Univ. China 2018, 17, 705-711. [CrossRef]

52. Choi, E.-M.; Kim, A.-J.; Kim, Y.-O.; Hwang, J.-K. Immunomodulating Activity of Arabinogalactan and Fucoidan In Vitro. J. Med. Food 2005, 8, 446-453. [CrossRef] [PubMed]

53. Li, B.; Lu, F.; Wei, X.; Zhao, R. Fucoidan: Structure and Bioactivity. Molecules 2008, 13, 1671-1695. [CrossRef] [PubMed]

54. Ermakova, S.; Men'Shova, R.; Vishchuk, O.; Kim, S.-M.; Um, B.-H.; Isakov, V.; Zvyagintseva, T. Water-soluble polysaccharides from the brown alga Eisenia bicyclis: Structural characteristics and antitumor activity. Algal Res. 2013, 2, 51-58. [CrossRef]

55. Pierre, G.; Graber, M.; Rafiliposon, B.A.; Dupuy, C.; Orvain, F.; Crignis, M.D.; Maugard, T. Biochemical Composition and Changes of Extracellular Polysaccharides (ECPS) Produced during Microphytobenthic Biofilm Development (Marennes-Oléron, France). Microb. Ecol. 2011, 63, 157-169. [CrossRef] 
56. Pierre, G.; Zhao, J.-M.; Orvain, F.; Dupuy, C.; Klein, G.; Graber, M.; Maugard, T. Seasonal dynamics of extracellular polymeric substances (EPS) in surface sediments of a diatom-dominated intertidal mudflat (Marennes-Oléron, France). J. Sea Res. 2014, 92, 26-35. [CrossRef]

57. Liu, H.; Jiang, W.; Bi, Y.; Luo, Y. Postharvest BTH treatment induces resistance of peach (Prunus persica L. cv. Jiubao) fruit to infection by Penicillium expansum and enhances activity of fruit defense mechanisms. Postharvest Biol. Technol. 2005, 35, 263-269. [CrossRef]

58. Bradford, M.M. A rapid and sensitive method for the quantitation of microgram quantities of protein utilizing the principle of protein-Dye binding. Anal. Biochem. 1976, 72, 248-254. [CrossRef]

59. Hagen, S.F.; Borge, G.I.A.; Bengtsson, G.B.; Bilger, W.; Berge, A.; Haffner, K.; Solhaug, K.A. Phenolic contents and other health and sensory related properties of apple fruit (Malus domestica Borkh., cv. Aroma): Effect of postharvest UV-B irradiation. Postharvest Biol. Technol. 2007, 45, 1-10. [CrossRef]

60. Budini, R.; Tonelli, D.; Girotti, S. Analysis of total phenols using the Prussian Blue method. J. Agric. Food Chem. 1980, 28, 1236-1238. [CrossRef]

61. Bruce, R.J.; West, C.A. Elicitation of Lignin Biosynthesis and Isoperoxidase Activity by Pectic Fragments in Suspension Cultures of Castor Bean. Plant Physiol. 1989, 91, 889-897. [CrossRef] [PubMed]

Publisher's Note: MDPI stays neutral with regard to jurisdictional claims in published maps and institutional affiliations.

(C) 2020 by the authors. Licensee MDPI, Basel, Switzerland. This article is an open access article distributed under the terms and conditions of the Creative Commons Attribution (CC BY) license (http://creativecommons.org/licenses/by/4.0/). 